\title{
Cloud Database Implementation in Digital Libraries Based on Android and JS Client
}

\author{
Djamaludin $^{1}$, Mohammad Ridwan ${ }^{2}$, Naufal Hidayat ${ }^{3}$ \\ \{djamaludin@unis.ac.id ${ }^{1}$, mridwan@unis.ac.id ${ }^{2}$, naufal.hidayat9h@gmail.com ${ }^{3}$ \} \\ Informatics Engineering Study Program, Islamic University of Sheikh Yusuf Tangerang, St. \\ Maulana Yusuf Tangerang 15118, Indonesia ${ }^{1,2,3}$
}

\begin{abstract}
With this rapid development, people, especially students, tend to spend more time just playing Android smartphones and not utilizing technological developments to create something useful but only for playing games, accessing social media and chatting that tend to be less us eful. Digital Library is an application that can help students to be able to read books anytime and anywhere without having to come directly to the library, this application is built with the Android platformas an information page while for administrators using the JS Client. We use the Firebase cloud database for realtime data storage.
\end{abstract}

Keyword: smartphone, android, ebook, Digital Library

\section{Introduction}

The development of Cloud Computing Technology in the millennial era that continues to grow and develop so fast, even every day is always growing new innovations to break a change. According to Erik Kurniaw an "Definition of Cloud Computing is a model that allows for ubiquitous (wherever and whenever), convenient, on-demand network access to computing resources (for example: netw orks, servers, storage, applic ations, and services) that can be quickly released or added. Cloud Computing as an information technology service that can be utilized by users with a network / internet based. Where a resource, software, information and application is provided for use by other computers that need it. Cloud computing has two words Cloud and Computing. Cloud which means the internet itself and computing is a computational process "[2]. With this rapid development, people, especially students, tend to spend more time just playing Android smartphones and not utilizing technological developments to create something useful but only for playing games, accessing social media and chatting that tend to be less useful and coupled with a lack of interest in reading books even though books are an important means for students to add insight and reference for learning. Students at the Shaykh Yusuf Islamic University (UNIS) chose to go to the library to find books and look for references for their final project but the library cannot be accessed every day due to various factors such as holidays, or national holidays so students at UNIS cannot visit them. Some examples of research that previously existed are Researchers by Agung Wahyudi "Development of an Android-Based Digital Library Using the Scrum 
Method"[6]. The application in this study does not yet have the feature of reading books in the form of e-books directly on smartphones and the database used is still local. The author tries to develop applications by adding features to read books directly in the form of e-books, integrated into the campus system, and using a database in the form of cloud to be accessed anytime and anywhere online. Based on the background that the authors describe, the writer will make "Implementation of a Cloud Database in the Android and JS Client-Based Digital Library" making it easier for students to access the library anytime and anywhere to read and find book references.

\section{Research Methods}

\subsection{Scrum}

The method used in this study is the scrum method which has several stages, namely Product backlog, Sprint planning metting, Daily Scrum, Sprint review metting, Sprint retrospective.

- Product Backlog, The product backlog aims to determine what priorities must be carried out during the sprint w ork, namely softw are planning planning meetings conducted in accordance with the agreed duration. Product backlog involves all related teams, from the Product Owner, Scrum Master, to the development team.

- Sprint Planning, Discuss the purpose or each feature in accordance with the wishes of the owner, and here the team determines the product how many hours it takes to carry out work on each feature.

- Daily Scrum, In this phase, each team member shares what has been done, and what will be done on that day. Team members can also report obstacles encountered during work. Daily scrum is done every day during the sprint.

- Sprint Review, Sprint review is a time for team members to demonstrate anything that was successfully completed in one sprint. Sprint review is done after one sprint work is complete.

- Sprint Retrospective, A sprint retrospective is done at the end of each sprint. In this meeting, each team member (including the Scrum Master and Product Owner) expressed their opinions regarding team performance during implementing Scrum without discussing the technical side of the project that was undertaken. 


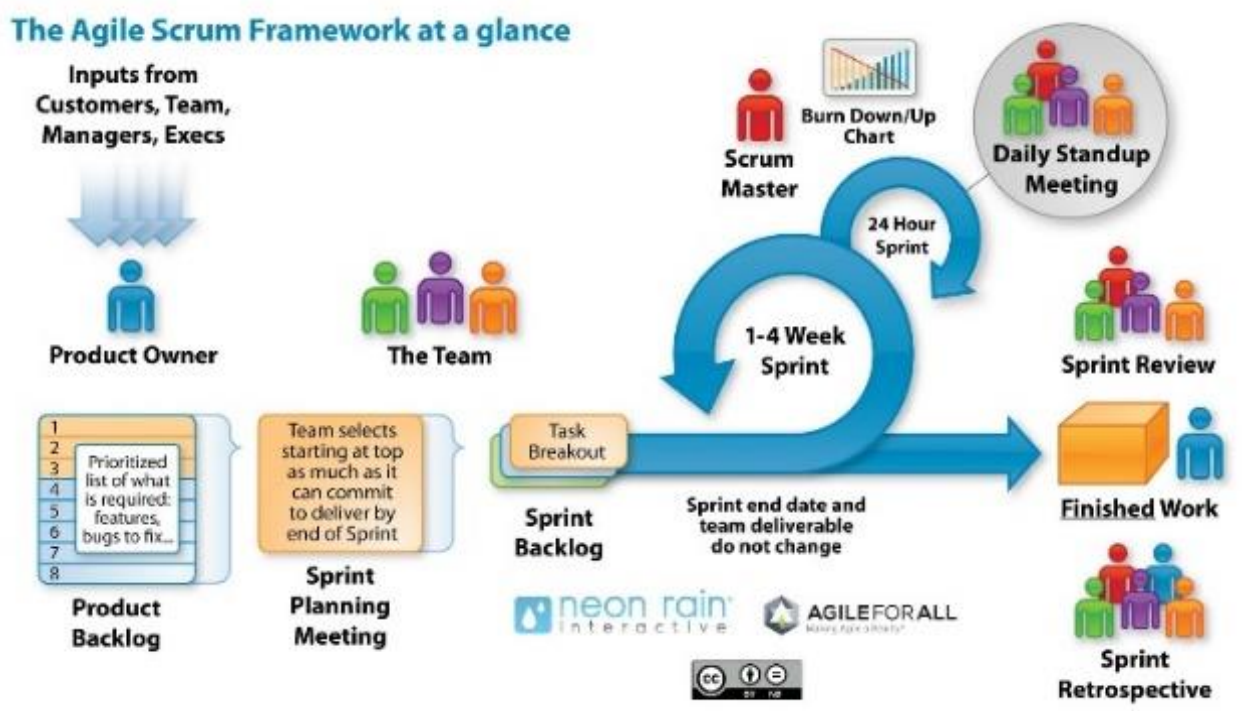

Figure 1. Methods Scrum

\section{Result And Discussion Research}

3.1. Current Systems Analysis

After making observations at the Shaykh Yusuf Islamic University Library in Tangerang, the author obtained a scheme when students searched and read books. 


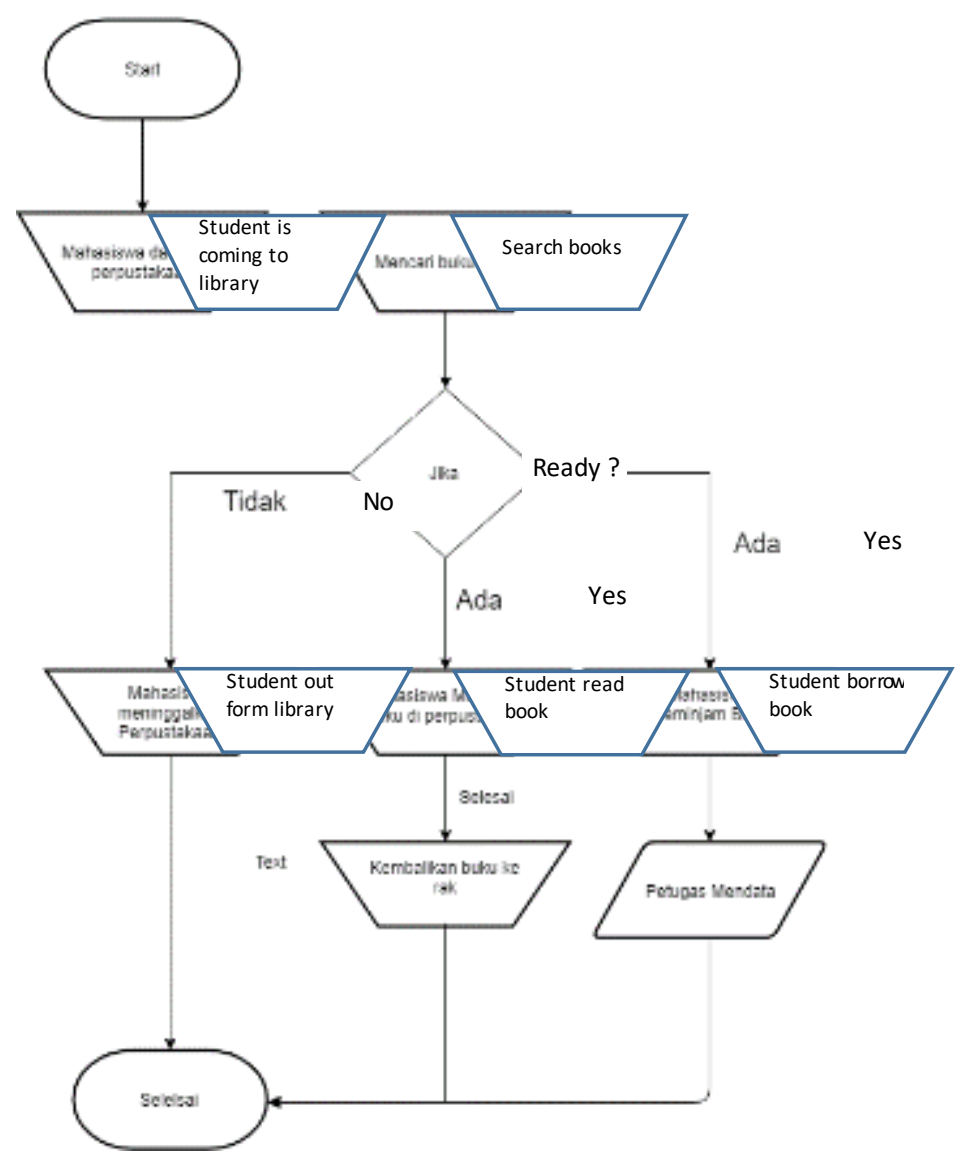

Figure 2. Manual System Analysis

3.2. General Description of The New System

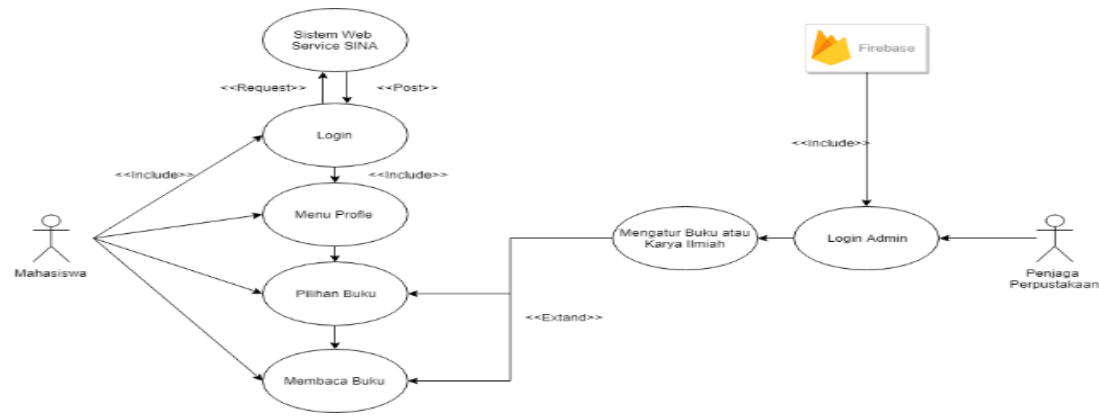

Figure 3. General Description of The New System 
- Students log into the application that is integrated with SINA UNIS.

- Students are directed to the profile menu whose data is taken from SINA UNIS

- Students can choose or search for the desired book

- Students can read books directly on a smartphone.

- The Library Guard login as an admin connected to the cloud.

- Library Guard manages books or scientific works that you want to add, delete, and update.

\subsection{Proposed System Analysis}

- Login Procedure, In this procedure the students enter their NIM and password in accordance with the account at SINA UNIS

- Procedure Profile Menu, In this procedure students as users can see their personal data from the SINA UNIS system.

- Procedure for Selection a Book, In this procedure students can choose the reading book menu as desired.

- Procedure for Reading Book, In this procedure students can choose the menu of reading books as they are looking for. In this procedure students can see the appearance of books in the form of e-books that can be read at any time.

- Library Guard Menu Procedure, In this procedure the library keeper will log in as an admin, a display will appear to process the collection of books or scientific works on the application

\subsection{Testing Method}

In this study the authors plan to use the Black Box testing method. Black Box Testing is testing the fundamental aspects of the system without regard to the internal logic structure of the software. This method only focuses on the functional requirements of the software or its exterior just like the black box image that only looks outside without knowing how the contents of the box. Test data is executed on the software and then the output of the software is checked if it is as expected.

Blackbox trials function to find errors in several categories, including:

- Finding functions that are incorrect or missing in a software.

- Look for interface errors that occur when the software is run.

- To find out errors in data structures or external database access in an application.

- Test the performance of the software.

- Initialize and find fault with the termination of the software itself.

\subsection{Database Specifications}

This is the design of data exchange from the UNIS academic system to the applic ation to be built 
Table 1. Webservice UNIS academic system to app

\begin{tabular}{|c|c|c|c|c|c|c|c|}
\hline No & Base Uxl & $\begin{array}{l}\text { End } \\
\text { Point }\end{array}$ & $\begin{array}{l}\text { Request/ } \\
\text { Response }\end{array}$ & $\begin{array}{l}\text { Name } \\
\text { Column }\end{array}$ & $\begin{array}{l}\text { Tipe } \\
\text { Data }\end{array}$ & Nullable & $\begin{array}{c}\text { Sumbex } \\
\text { SWebrervice } \\
\text { Lain }\end{array}$ \\
\hline \multirow{15}{*}{1} & \multirow{15}{*}{$\begin{array}{l}\text { sina.unis. } \\
\text { acidi/ison } \\
\text { conn/inde } \\
\text { x.phplisa } \\
\text { nconn }\end{array}$} & \multirow{15}{*}{$\begin{array}{l}\text { Aogineh } \\
\text { sogk }\end{array}$} & \multirow{3}{*}{ Request } & token & string & not null & \multirow{3}{*}{ Login } \\
\hline & & & & 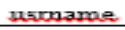 & string & not null & \\
\hline & & & & password & string & not null & \\
\hline & & & \multirow{3}{*}{ Response } & data & & & \\
\hline & & & & success & & & \\
\hline & & & & error & & & \\
\hline & & & \multirow{9}{*}{ Response } & username & & & \\
\hline & & & & nama & & & \\
\hline & & & & tmplax & & & \\
\hline & & & & tagllbr. & & & \\
\hline & & & & alamaat & & & \\
\hline & & & & bp & & & \\
\hline & & & & email & & & \\
\hline & & & & 水 & & & \\
\hline & & & & namanunit & & & \\
\hline \multirow{6}{*}{2} & \multirow{6}{*}{$\begin{array}{l}\text { sina.unis. } \\
\text { ac.id/upl } \\
\text { oads/fote } \\
\text { mhs' }\end{array}$} & \multirow{6}{*}{ /thumb } & \multirow{3}{*}{ Request } & \multirow{3}{*}{ нuscuarae } & \multirow{3}{*}{ string } & \multirow{3}{*}{ not null } & \\
\hline & & & & & & & \\
\hline & & & & & & & \\
\hline & & & \multirow{3}{*}{ Response } & \multirow{3}{*}{ image } & & & \\
\hline & & & & & & & \\
\hline & & & & & & & \\
\hline
\end{tabular}

and then the following is a hierarchical description of the cloud database design that will be used.

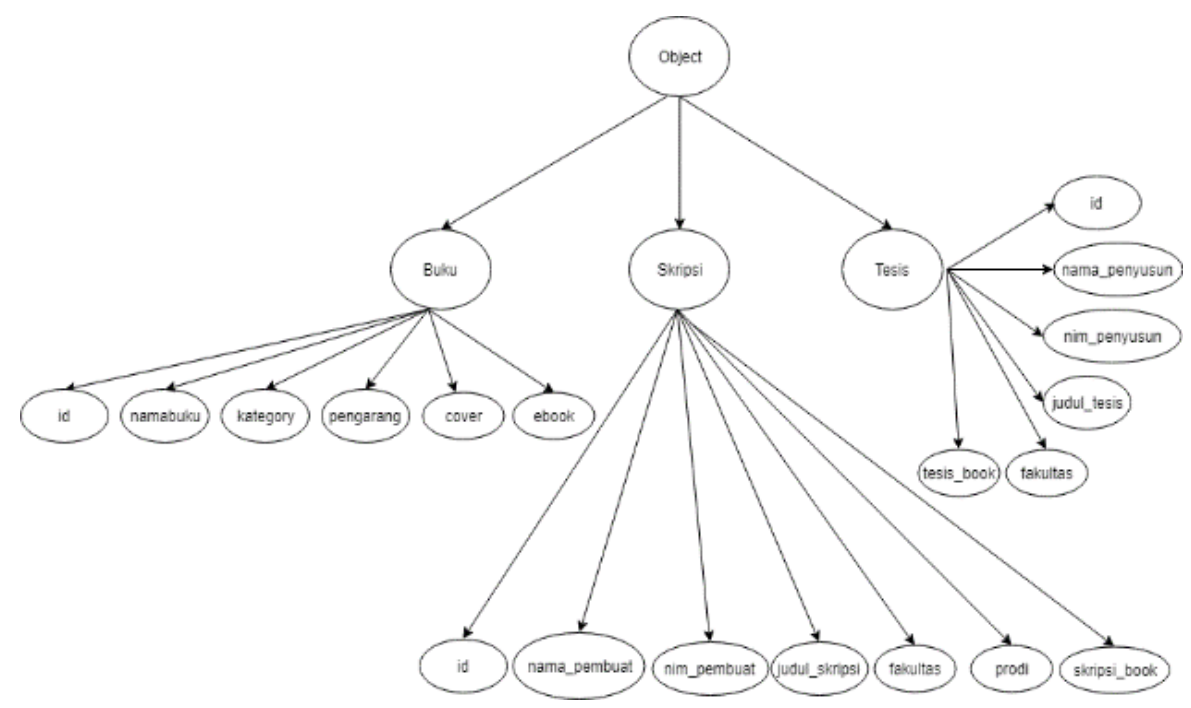

Figure 4. Json Tree Cload Database App 


\section{Conclusion}

Some conclusions that can be drawn from the Implementation of the Cloud Database in Digital Libraries Based on Android and JS Client are as follows:

- By using this application students can already access the library using an Android smartphone anywhere and anytime.

- With this digital library application makes it easy for students to find book references..

- This application is designed using the Android Studio IDE with Database and Storage from Firebase.

\section{Suggestion}

In the research conducted by the author to create a Digital Library Application at the Unis Library in Tangerang, there are several suggestions that are expected so that other system developers can continue and develop this Library Application for the better. Among them are:

- This application needs to use internet access to access the library book collection, thus not being able to read books when there is no internet. It is hoped that the Library Application developer can make it accessible offline.

- The method of searching books is still manual by checking one by one the collection is expected that developers can add a search feature to the application to facilitate searching

- In this application you can read books but don't have a favorite feature to save favorite books.

\section{References}

[1] P. Humisar Parsaorantua, Y. Pasoreh, and S. A. Rondonuwu, "e-journal 'Acta Diurna' Volume VI. No. 3. Tahun 2017," e-journal "Acta Diurna," vol. VI, no. 3, 2017.

[2] E. Kurniawan, "Implementasi Rest Web Service Untuk Sales Order Dan Sales Tracking Berbasis Mobile," J. EKSIS, vol. 07, pp. 1-12, 2014.

[3] S. Khuzaemah, "Perancangan Sistem Pendukung Keputusan Penilaian Kinerja Organisasi Menggunakan Metode Simple Additive Weighting (SAW) Pada Kemenko Bidang Perekonomian Jakarta Pusat," Siti Khuzaemah, 2016. [Online]. Available: https://widuri.raharja.info/index.php/SI1314475516\#cite_note-fauzi2015-15. [Acc essed: 24-Mar-2019].

[4] F. Nugroho, P. Muljono, and I. Hermadi, "Development of online public access catalog (opac) based android on library," vol. 7, no. 2, pp. 29-45, 2017.

[5] Helsa, "Konsep Dasar Perpustakaan," 12 July 2014, 2014. [Online]. 
Available: http://pp.ktp.fip.unp.ac.id/?p=24.

[6] A. Wahyudi, "Pengembangan Perpustakaan Digital," vol. 11, no. 2, pp. 128$133,2018$.

[7] M. H. Qamaruzzaman and F. Haris, "Aplikasi Mobile Perpustakaan Berbasis Android (Studi Kasus Perpustakaan STMIK Palangkaraya," vol. 2, no. 114.

[8] Dicoding Indonesia, "Introduction," 28 Desember, 2018. [Online]. Available: https://www.dic oding.com/academies/51/tutorials/1164. [Accessed: 15-Mar2019].

[9] S. P. Ahmad Imaduddin, Menjadi Android Developer Expert. 2018.

[10] Ariata, "Apa Itu JavaScript? Pemahaman Dasar Mengenai JavaScript bagi Para Pemula," January 23rd, 2019, 2019. [Online]. Available: https://www.hostinger.co.id/tutorial/apa-itu-javascript/. [Accessed: 28-Mar2019].

[11] G. Developer, "Firebase Realtime Database," January 24, 2019. [Online]. Available: https://firebase.google.com/docs/database/?hl=id. [Accessed: 14Mar-2019].

[12] J. M. Putera et al., "Rancang Bangun Aplikasi Berbasis Android Dengan PenerapanWeb Service Pada Sistem Informasi Perpustakaan( Studi Kasus : Perpustakaan Daerah Kalimantan Barat )," pp. 1-5.

[13] V. O. H. Wongso, "Pengenalan Java (Console)," 2018/02/02/, 2018. [Online]. Available: https://sis.binus.ac.id/2018/02/02/pengenalan-java-console/.

[14] Tata Sutabri, "Konsep Sistem Informasi," April 2012, 2012.

[15] Sinudarwati, "Perancangan Sistem Informasi Penanganan Keluhan Konsumen Berbasis Web Pada PT Industira Batu Ceper Tangerang," Febuari 2018, 2018. 